\title{
Flipped for a Betterment: The Acceptance Level Towards Flipped Learning Among Malaysian ESL Learners
}

\author{
Woon Wern Lie ${ }^{1} \&$ Melor Md. Yunus ${ }^{2}$ \\ ${ }^{1}$ Universiti Kebangsaan Malaysia, Bangi, Malaysia \\ ${ }^{2}$ Department of Innovation in Teaching \& Learning, Universiti Kebangsaan Malaysia, Bangi, Malaysia \\ Correspondence: Woon Wern Lie, Postgraduate (Md. TESL), Universiti Kebangsaan Malaysia, Bangi, \\ Selangor, Malaysia. \\ Received: April 15, 2019 \\ Accepted: April 28, 2019 \\ Online Published: April 30, 2019 \\ doi:10.20849/jed.v3i1.569 \\ URL: https://doi.org/10.20849/jed.v3i1.569
}

\begin{abstract}
Shall we flip for a betterment? Flipped learning is a common method that is widely used in secondary and tertiary education. So, how about primary education? Many would question whether this method could be utilised effectively in a primary school ESL classroom. Undoubtedly, this is indeed one of the main issues that worried the authorities. Due to the lack of empirical studies, the Malaysian society was not confident to use flipped learning in primary school. So, this study would therefore explore the acceptance level of flipped learning approach among primary school students, to check out the which construct affects the acceptance level the most as well as to find out the factors that influence their choice. This research was hoped to provide insights into attracting more educators to try out flipped learning in ESL classroom. In this study, it used a mixed-method design where quantitative data from survey and responses from group interviews were used to measure the outcomes. Initially, all Year 6 students from a primary school in Malaysia were chosen to experience flipped learning. Then 215 students were chosen as survey participants while another 15 among them were selected for focus group interviews. It had found out that effort expectancy was the major contributor towards the acceptance level and there are three factors that affect the behavioral intention,namely, clear interface, time efficacy and user friendly. This positive result was hoped to attract more educators to flip for a betterment.
\end{abstract}

Keywords: flipped learning, acceptance level, ESL, UTAUT, effort expectancy, teaching and learning

\section{Introduction}

It is undeniable that new developments in information and communication technologies (ICT) has rapidly outpaced current knowledge, the future educators should promptly decide on when and how to use technology effectively (Angeli, C., \& Valanides, N., 2009). Moreover, in this $21^{\text {st }}$ century, Computer-Assisted Language Learning (CALL) is claimed by Yunus et. al to be very prevalent (Yunus, M.M., Nordin, N., Salehi, H., Embi, M.A., \& Salehi, Z., 2013); (Yunus, M.M., Salehi, H., \& Amini, M., 2016). So, to flip a classroom or not to flip is indeed a good thing that one shall ponder deeply. Yunus (2018) in her paper had also supported the statement by stating that innovation evolved frequently or in fact all the time (Yunus, M.M., 2018). As a result, the evolution had tremendously changed the English Language Teaching (ELT) especially alongside with technology (Yunus, M.M., 2018). Hence, teachers should increase their capacity to accept technology like flipped learning as a teaching and learning tool which is to help increasing the readiness of the students for their future.

Meanwhile, we can realise that previous studies focus on how technology is used rather than its implementation in creating alternative learning opportunities for students (Inan, F.A., \& Lowther, D.L., 2010). Moreover, limited research also exists within the framework of teachers' use of technology, where the factors that affect students' acceptance level are still being questioned (Ifenthaler, D., \& Schweinbenz, V., 2013). Additionally, some research concluded that there were not many technology acceptance studies that provided significant correlations between technology and learning because most of the studies occurred outside the K-12 education field (El-Gayar, O., Moran, M., \& Hawkes, M. 2011; Oliver, M., 2013) or can be known as primary level in Malaysia. Therefore, this paper was to check out the acceptance level of Malaysian primary school students towards flipped learning approach and to find out the main contributor towards the learner's acceptance level towards flipped learning approach. 


\section{Literature Review}

\subsection{The Development of Flipped Learning Approach}

There had been many studies on flipped learning approach since 2014, based on the fact that flipped learning was first begun to emerge in 2013 by Jonathan Bergmann and Aaron Sams, two chemistry teachers from Colorado (Arfstrom, K.M., \& Network, P.D., 2013). We can realise that most of the studies focus on either the learner's perception or even the implementation of the approach rather than finding out the factors that affect the learner's acceptance level. Meanwhile, another type of popular studies on flipped learning approach is to find out the potential of this approach where both pros and cons of the approach were being discussed. So, what is lacking in this flipped learning approach is studies on the effectiveness of the approach using the right framework as well as the acceptance level in which the factors that influence the learners' choices are being discussed. Furthermore, Mohamad, Ghazali, and Hashim (2018) claimed that teachers must be aware of how to integrate technology as one of the learning tools in the teaching of English as a Second Language (ESL) (Mohamad, M., Ghazali, N., \& Hashim, H., 2018). Hence, more studies on the acceptance level should be conducted using the right conceptual framework

\subsection{Studies on the Potential of Flipped Learning in Malaysia}

In term of Malaysia context, most of the studies that were related to either flipped learning were conducted in secondary and tertiary level. Less research or study was being carried out in the primary level. In fact, Handam et al., (2013) stated that flipped classroom was initially implemented merely at the university level before it had been widely utilised in schools in Science, Technology, Engineering and Mathematics (STEM) (Arfstrom, K.M., \& Network, P.D., 2013). Then, when flipped learning approach was first introduced in Malaysia, Embi, Hussin and Panah (2014) had conducted a study on the readiness among graduates and postgraduate students in Universiti Kebangsaan Malaysia (Embi, M.A., Hussin, S., \& Panah, E., 2014). The study was to identify different factors that would affect the readiness towards flipped learning approach. For instance, the accessibility of technology, skills to go online, relationships, motivation, ability to utilise online audios or videos, internet discussions, importance to success, etc. (Embi, M.A., Hussin, S., \& Panah, E., 2014). The results had shown that Malaysian graduate were ready to adopt the flipped learning approach. They also recommended that future studies on flipped learning approach should further measure the real impact of flipped learning on Malaysian students. So, this study was indeed appropriate as it was to check out the acceptance level of flipped approach among primary school student.

Up next was a research which was done by Attaran and Zamzami (2015), they carried out a study evaluating a class in University of Malaya in which flipped learning was applied and also to examine students' perceptions and feedback towards flipped classroom. The results had indicated that most of the students in tertiary level had positive perceptions towards the flipped classroom approach and they would recommend flipped learning for others (Zainuddin, Z., \& Attaran, M., 2016). Other than that, flipped learning approach had found out to generate positive impacts for shy and quiet students, international students that were not fluent in English language and lastly full-time students who had more time for learning (Zainuddin, Z., \& Attaran, M., 2016). Hence, their studies had provided an insight for this study to carry out in primary level in the hope that the students would have a good basis in mastering English language which might help them to achieve at least B1 or B2 according to CEFR standard.

Besides that, Singh. H, Singh.C, Mohtar and Mostafa (2017) had done a review research on flipped classroom approach for teaching communication skills in English. Instead of primary or secondary education in Malaysia, they focused their review studies on TVET education (Singh, H.S., Singh, C.K., Mohtar, T.M., \& Mostafa, N.A., 2017). They studied 5 studies related to flipped learning approach at TVET. they found out that Rajesh (2015) had claimed that learners could have various hands on activities and therefore help in promoting more meaningful learning (Rajesh, M., 2015). Then, they also stated that Roehl, Reddy and Shannon (2013) had claimed that the flipped learning approach could help in improving the learning experiences and even to capture the attention of millennial students (Roehl, A., Reddy, S.L., \& Shannon, G.J., 2013). This is very vital as we must know that the learners were no longer generation $\mathrm{X}$ or $\mathrm{Y}$. Instead, they are generation $\mathrm{Z}$ and alpha which are computer literate. their findings had indicated that this flipped learning approach would give a positive impact towards the second language learners and it is possible to fill the research gap in teaching and learning context (Singh, H.S., Singh, C.K., Mohtar, T.M., \& Mostafa, N.A., 2017).

However, despite of all the benefits discussed, Yunus et.al. (2018) had claimed that unstable internet connection as well as time constraints would hinder a better opportunity for learning engagement (Yunus, M.M., Hashim, H., Ahmad, A.R., Sulaiman, N.A., Fadzila, A.S., Nurfitri, A., Asyraf, M.N., \& Hasmirah, N., 2018). So, it would be 
wise to take precautions on these two important points in order to make flipped learning a better experience in primary ESL classroom.

\section{Research Methodology}

This study was a mix-method research in which it combined a quantitative study with a qualitative study. A survey study, group interviews (focus group) as well as an observation of participants' interactions were carried out in this study. Although mixed method was applied in this study, the principal research design was still quantitative and it would apply a survey research to answer the research questions

\subsection{Data Collection}

The quantitative data of this non-experimental study were collected using questionnaires through an online system which is known as Polldaddy (polldaddy.com). Since the aim of this research was to describe and elaborate the students' acceptance level, thus, it was suitable to use survey research as concepts were described and elaborated based on responses collected from questionnaires. Moreover, Chua (2016) claimed that a survey research could be used in the field of education in order to get answers directly from the subjects and also to describe a phenomena which interests the researchers (Chua, Y.P., 2017). For this reason, this research paper used survey research as one of the methods to make predictions of the use and acceptance level of flipped learning approach in Malaysian primary school context.

Then, this study also included qualitative data which were via focus groups, group interviews together with an observation of participants' interactions. The focus group method was believed to play an important role in facilitating an in-depth exploration towards an idea or a topic (Stewart, D.W., \& Shamdasani, P.N., 2014). So, in this study, three focus group interviews were held. Each focus groups was consisted of 5 members. Focus group 1 consisted of participants with high proficiency level, focus group 2 was participants with intermediate proficiency level while focus group 3 was for participants with low proficiency level and yet they could clearly understand English. Within the focus groups, an observation of participants' interactions was also being conducted. It must be noted that the participants were young primary school ESL learners who were not used to interviews. They might be fear to voice out their opinions. Therefore, these observations could capture a complete picture of the participants' feelings. Just by observing the participants' reactions and body language together with facial expressions, it was believed that some subtle feelings and attitudes of participants could be discerned effectively. Hence, the data collected using observations could reveal a more holistic picture of participants' feelings.

\subsection{Data Analysis}

Since this study was a mixed method design. All the data were analyzed both quantitatively and also qualitatively. All the data analysis were based upon the theoretical framework - the UTAUT model—which also guided the 2 research questions in this study. For quantitative data, results were collected, processed and analyzed using frequency counts and percentage distribution. After the data was analyzed, it was presented in tables and charts form.

Then, for qualitative data, it was to further support or back up the findings from quantitative data which is the survey from the questionnaire. The group interviews were transcribed and analysed for emerging categories in which the data were analyzed by using an inductive approach where it allowed the prevailing pattern, themes and categories of the research findings. The analysis of the transcripts comprised of determining a list of themes, labeling the data and sorting the content of the data into meaningful categories. All the themes were based on the UTAUT model. In fact, the group interviews transcripts were used to provide extra information on this subject and to triangulate students' opinions. The student interviews were analyzed and coded in the same manner as the questionnaires. Furthermore, they are young primary school students who might not be able to express their thoughts as detailed as the adults. So, triangulation between two sources of data was done.

\section{Findings and Discussions}

\subsection{The Acceptance Level Towards Flipped Learning Among ESL Learners}

As mentioned in the earlier section, the investigation into the student's level of acceptance towards flipped learning was based on a modified version of Unified Theory of Acceptance and Use of Technology (UTAUT) model. The report of the findings reveals the ESL learners' perception towards flipped learning through four key constructs of the UTAUT model, namely, 1) performance expectancy(PE); 2) effort expectancy(EE); 3) facilitating condition(FC); 4) social influences(SI) and last but not least this study would study the behavioural intention(BI) on whether the learners would accept this learning method and continue to use it in the future. Since the sample size for this study was large, median was not used to measure the results, instead this study 
opted for mean average score to observe the scores for each constructs. This study would stress that the mean scores obtained for each constructs would only indicate where on the Likert scale the learners' answers fell. Refer to Table 1.

Table 1. Mean scores for each category

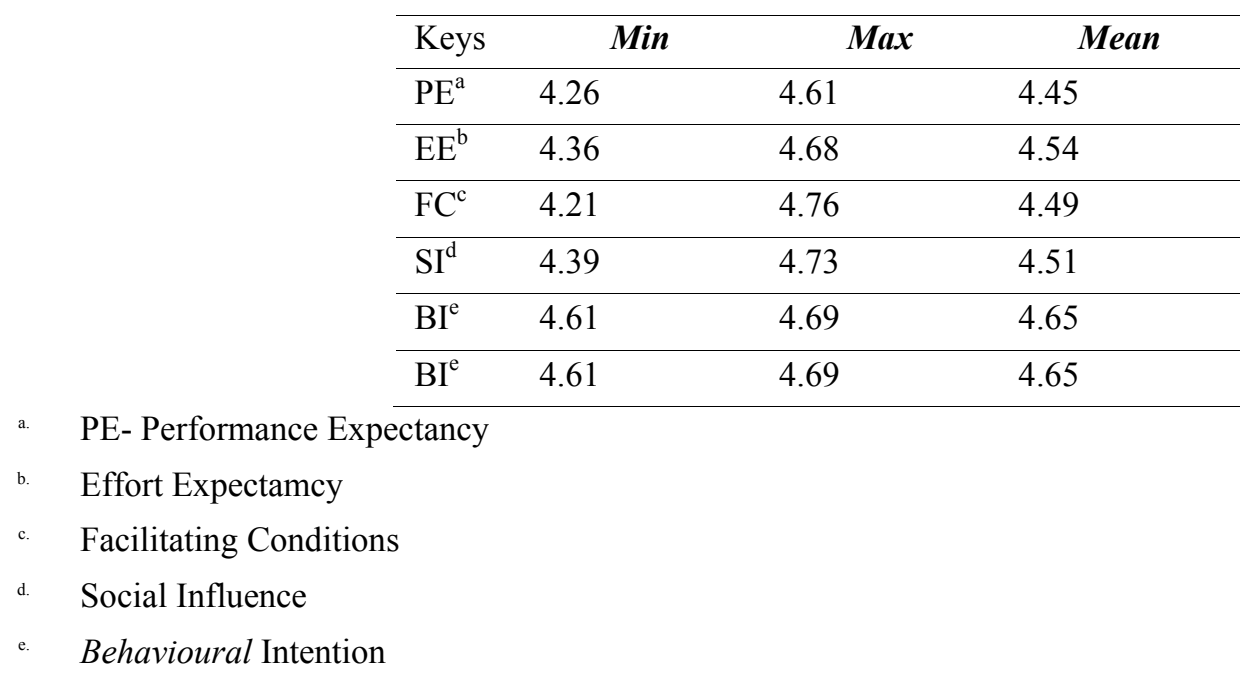

As shown in Table 1, it was found out that all constructs scored between 4.45 and 4.65 for the mean score. The mean score obtained for four key constructs of the UTAUT model was as followed, performance expectancy 4.45, effort expectancy 4.54, facilitating condition 4.49 and social influences 4.51 . These indicated that among the four key constructs, the respondents rated effort expectancy as the highest key construct, while performance expectancy as the lowest. In term of behavioral intention, which means that whether or not the learners would prefer to continue learning English using this approach in the future, it scored a very high mean score too, which was as high as 4.65 . This data indicated that $93 \%$ of the learners agree and plan to continue using flipped learning approach.

\subsection{Main Contributor That Affects the ESL Learner's Acceptance Level}

There were four main key constructs based on UTAUT model, namely, Performance Expectancy, Effort Expectancy, Facilitating Condition and Social Influence. Therefore, in order to answer research question 1, we would turn each mean scores for the 4 main key constructs into percentages. The category that scored the highest percentage would be the main contributor that influenced the student's level of acceptance towards flipped learning. This quantitative data result would be further triangulated with the frequency counts of the themes emerged from the qualitative data (refer to Table 2)

Table 2. Percentages for the 4 main constructs

\begin{tabular}{|c|c|c|}
\hline Keys & Mean & Percentages(\%) \\
\hline $\mathrm{PE}^{\mathrm{a}}$ & 4.45 & 89.0 \\
\hline $\mathrm{EE}^{\mathrm{b}}$ & 4.54 & 90.8 \\
\hline $\mathrm{FC}^{\mathrm{c}}$ & 4.49 & 89.8 \\
\hline $\mathrm{SI}^{\mathrm{d}}$ & 4.51 & 90.2 \\
\hline
\end{tabular}

So, by referring to Table 2, we could realise that effort expectancy had scored the highest percentage with a total of $90.8 \%$. This construct was found out to be the main contributor that influence the acceptance level towards flipped learning. It would be best to study the statements in this category for a better elaboration on factors that affect the learner's choice. Thus, there were four main statements under this category, which were as followed,

- I would find the method of learning English using flipped learning method is easy to use. 
- The instructions given is clear and can be understood easily

- The instructions given in the video are clear and can be understood easily.

- It would be easy for me to become skillful at learning English using flipped learning approach

Hence, we know that effort expectancy was all about usage. It focused on whether or not the proposed method was easy or difficult to comprehend. Not forgetting about the instructions given by the instructors. Since Effort Expectancy (EE) category had found out to be the main contributor that affects the acceptance level, it was wise to triangulate this quantitative data with the qualitative data, focusing on effort expectancy category. (refer to Table 3)

Table 3. Frequency counts for the themes that emerged in focus group interviews

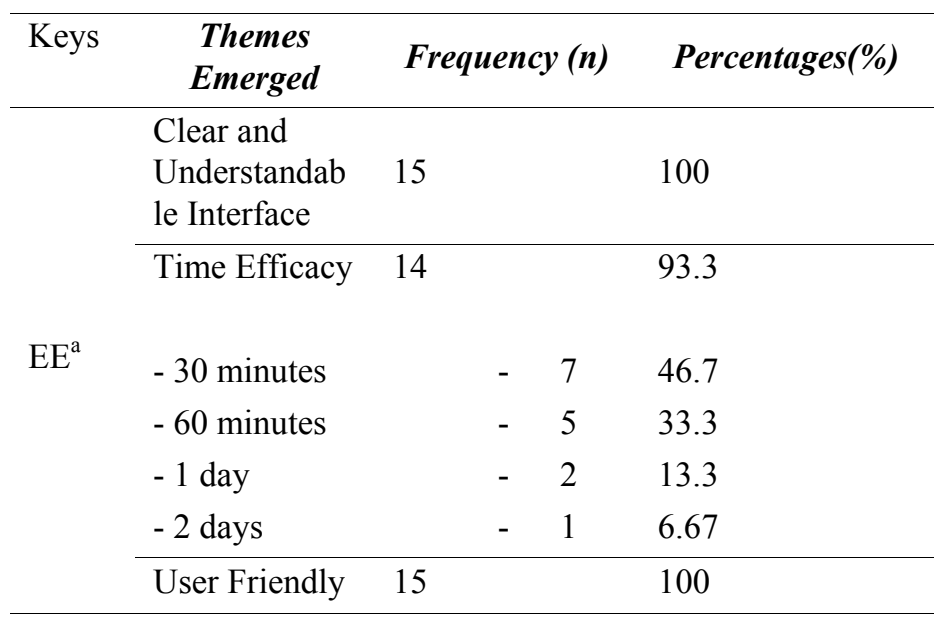

Based on Table 2, again, Effort Expectancy (EE) category had found out to achieve the highest frequency count which in turn to achieve the highest percentage among 4 key constructs. Then in Table 3, based on the interviews, it revealed that flipped learning was indeed user-friendly. All the participants $(100 \%)$ stated that this learning method was easy to use and most of them could figure out how does it work in between 30 minutes to 1 day. Quoted, 'Do you think this type of learning method outside the school is complicated or easy to use?' The participants all gave the same answers. 'Quite easy', 'Easy', 'Very easy', 'I agree with him, very easy' etc. So, all of them $(100 \%)$ stated flipped learning was easy and less effort is needed.

Then, they also claimed that they used very little time to fully understand the learning method. Quoted, 'How long do you need to understand this learning method?'. 7 of them answered 'Half an hour', 5 of them answered ' 1 hour', 2 of them answered ' 1 day' and 1 of them needs ' 2 days'. We could consider less than a day to match the theme- Time Efficacy (little time needed). So, a total of $93.33 \%$ agreed that the time efficacy for this learning method was excellent.

Furthermore, the flipped learning method had clear and understandable interface. When the users claimed the method to be clear and understandable, this would optimise the learning experience. In fact, flipped learning was just flipping the traditional way of learning, not complicated at all. It was like doing pre-revision at home. Hence, this empirical study was important to let the educators know that Effort Expectancy aspect was the major factor or main contributor that influenced the acceptance level towards flipped learning. Moreover, they were young ESL learners. Complicated instructions or methods will surely affect their learning. Make it user friendly and of course with clear and understandable instructions. This result would further support what Angelova and Zhao (2016) claimed (Angelova, M., \& Zhao, Y., 2016). They stated in their paper saying that flipped learning approach had the power to transform a passive learner into an active one (Angelova and Zhao., 2016). Therefore, effort expectancy aspect was the factor that played a vital role to help transforming a passive learner into an active one.

\section{Conclusion and Implication}

The findings for this research indicated that effort expectancy exerts the most influence on the primary school ESL students' acceptance towards flipped learning. The suggestion for future English classes using flipped learning approach was to keep a clear and understandable interface and make it user friendly. Moreover, it is 
recommended that instructors should make the instruction clear. As long as it could be understood easily, it would surely increase the acceptance level among primary school students.

Then, performance expectancy aspect was found out to have a significant effect on participants' acceptance towards flipped learning. Flipped learning could improve study efficiency, facilitate intrinsic motivation, and cultivate the interest of learning English as well as the convenience of online learning resources were part of the reasons for participants to consider adopting flipped learning. Therefore, this study implied the design of English class for ESL students using flipped learning approach should take advantage all these in order to help improve ESL students' study performance

Last but not least, social influence and facilitating conditions had a certain degree of impact towards the flipped learning acceptance level among ESL students. It was suggested that the instructors ought to pay more attention to help primary school ESL students to get familiar with flipped learning method. In fact the school administrator should give full support towards their teacher in using flipped learning approach in ESL classroom.

This empirical study had showed that this was the right time to engage learners in this kind of authentic tasks and problem solving skill that they actually need in the future. In fact, Yunus (2018) had urged the educators to leave behind all the traditional teaching methods and try to opt for a different approach and particularly in a setting which is recognised internationally (Yunus, M.M., 2018). Let's flip for a betterment as this study had proven to us that effort expectancy construct is the main factor that influence learner's acceptance level. Flipping brings no harm! Let's flip for a betterment.

\section{Acknowledgment}

This research was supported by Faculty of Education, Universiti Kebangsaan Malaysia, under the grant GG-2018-001.

\section{References}

Angeli, C., \& Valanides, N. (2009). Epistemological and methodological issues for the conceptualization, development, and assessment of ICT-TPCK: Advances in technological pedagogical content knowledge (TPCK). Computers \& Education, 52(1), 154-168. https://doi.org/10.1016/j.compedu.2008.07.006

Angelova, M., \& Zhao, Y. (2016, January). Using an online collaborative project between American and Chinese students to develop ESL teaching skills, cross-cultural awareness and language skills. Computer Assisted Language Learning, 29(1), 167-85. https://doi.org/10.1080/09588221.2014.907320

Arfstrom, K.M., \& Network, P.D (2013). A white PAPer BAsed on the LiterAture review titLed A Review of flipped leARning. Noora Hamdan and Patrick McKnight, Flipped Learning Network.

Chua, Y.P. (2017). Developing a grounded model for educational technology leadership practices. Egitim ve Bilim, 42(189). https://doi.org/10.15390/EB.2017.6705

El-Gayar, O., Moran, M., \& Hawkes, M. (2011, April). Students' acceptance of tablet PCs and implications for educational institutions. Journal of Educational Technology \& Society, 14(2), 58-70.

Embi, M.A., Hussin, S., \& Panah, E. (2014). Flipped learning readiness among graduate and postgraduate students in UKM. Blended \& Flipped Learning: Case Stdies in Malaysian HEIs.

Ifenthaler, D., \& Schweinbenz, V. (2013, May). The acceptance of Tablet-PCs in classroom instruction: The teachers' perspectives. Computers in human behavior, 29(3), 525-534. https://doi.org/10.1016/j.chb.2012.11.004

Inan, F.A., \& Lowther, D.L. (2010, April). Factors affecting technology integration in K-12 classrooms: A path model. Educational Technology Research and Development, 58(2), 137-154. https://doi.org/10.1007/s11423-009-9132-y

Mohamad, M., Ghazali, N., \& Hashim, H. (2018, September). Secondary School Students' Perceptions on the Use of Google+ towards Improving ESL Writing Skills. International Journal of Emerging Technologies in Learning (iJET), 13(09), 224-238. https://doi.org/10.3991/ijet.v13i09.8479

Oliver, M. (2013, January). Learning technology: Theorising the tools we study. British Journal of Educational Technology, 44(1), 31-43. https://doi.org/10.1111/j.1467-8535.2011.01283.x

Rajesh, M. (2015, January). Revolution in Communication Technologies: Impact on Distance Education. Turkish Online Journal of Distance Education, (1), 62-88. https://doi.org/10.17718/tojde.26353 
Roehl, A., Reddy, S.L., \& Shannon, G.J. (2013, March). The flipped classroom: An opportunity to engage millennial students through active learning strategies. Journal of Family \& Consumer Sciences, 105(2), 44-49. https://doi.org/10.14307/JFCS105.2.12

Singh, H.S., Singh, C.K., Mohtar, T.M., \& Mostafa, N.A. (2017). A Review of Research on Flipped Classroom Approach for Teaching Communication Skills in English. International Journal of Academic Research in Business and Social Sciences, 7(10), 100-118. https://doi.org/10.6007/IJARBSS/v7-i10/3362

Stewart, D.W., \& Shamdasani, P.N. (2014, March). Focus groups: Theory and practice. Sage publications.

Yunus, M.M. (2018, May). Innovation in Education and Language Learning in 21st century. Journal of Sustainable Development Education and Research, 2(1), 33-34..

Yunus, M.M., Hashim, H., Ahmad, A.R., Sulaiman, N.A., Fadzila, A.S., Nurfitri, A., ... Hasmirah, N. (2018, January). MOOC as a Platform for Developing Writing Skills: Effectiveness and Challenges. Advanced Science Letters, 24(1), 199-201.

Yunus, M.M., Nordin, N., Salehi, H., Embi, M.A., \& Salehi, Z. (2013). The Use of Information and Communication Technology (ICT) in Teaching ESL Writing Skills. English Language Teaching, 6(7), 1-8. https://doi.org/10.5539/elt.v6n7p1

Yunus, M.M., Salehi, H., \& Amini, M. (2016). Impact of Using CALL on Iranian EFL Learners' Vocabulary Knowledge. English Language Teaching, 9(1), 173-187. https://doi.org/10.5539/elt.v9n1p173

Zainuddin, Z., \& Attaran, M. (2016, November). Malaysian students' perceptions of flipped classroom: A case study. Innovations in Education and Teaching International, 53(6), 660-670. https://doi.org/10.1080/14703297.2015.1102079

\section{Copyrights}

Copyright for this article is retained by the author(s), with first publication rights granted to the journal.

This is an open-access article distributed under the terms and conditions of the Creative Commons Attribution license (http://creativecommons.org/licenses/by/4.0/). 